\title{
Urinary Problems in Decompression Sickness ${ }^{\star}$
}

Athanasios Dounis, M.D. and Dionisios Mitropoulos, M.D.

The Naval Medical Hyperbaric Center, Piraeus Naval Hospital and Department of Urology, Athens Naval Hospital, Greece

\section{Summary}

The records of 25 patients with type II decompression sickness and urinary problems have been reviewed. Seventeen patients were professionals and 8 were above the age of 40. The disease appeared within the 1st hour of emergence from the water in $70 \%$ of the cases and within the first 4 hours in the remaining $30 \%$. Nine patients were diagnosed as paraplegic and two as tetraplegic. All patients had urinary disturbances and 14 were on Foley-catheter drainage during the decompression while 11 were on intermittent catheterisation. Fifteen patients had improved urinary function after recompression, 8 had some difficulty, 2 underwent a sphincterotomy and one a transurethral prostatectomy. The low percentage of complete recovery was due to the delayed arrival at the decompression chamber.

Key words: Diving; Decompression sickness; Urinary disturbances.

\section{Introduction}

Diving for sponge fishery is the main professional occupation of the young men in the South-East Aegean islands. Although the use of recompression has decreased the number of decompression sickness victims, patients with remaining neurological problems still present. During the last 20 years, although there is a decrease of the professional divers' accidents there is an increase of the number of patients with decompression sickness. This is due to the continuously increasing numbers of sport divers in Greece.

In Greece, the field of underwater medicine is covered mainly by the Naval Medical Service. The Naval School of Underwater Medicine is served by military and civilian doctors as well as paramedical staff. There are two big recompression chambers (Piraeus and Crete Naval Hospitals), a smaller one at the island of Kalymnos and a number of transportable 'one-person' chambers distributed among different seaside cities. Patients are transported by helicopters and by fixed wing aeroplanes.

* This paper was read at the 9th International Congress of Physical Medicine and Rehabilitation, Jerusalem, Israel, May, 13-18, 1984. 
Urinary disturbances are a very common complication in decompression sickness. The Kalimnian sponge divers have a traditional test for decompression disease: just after emerging from the water they try to pass urine and they repeat it 30 minutes later.

Although these urinary disturbances are not a rare phenomenon, no clear clinical picture has been described and furthermore, no standard policy has been established for their treatment.

\section{Material and methods}

We reviewed the records of 48 patients with decompression sickness who had

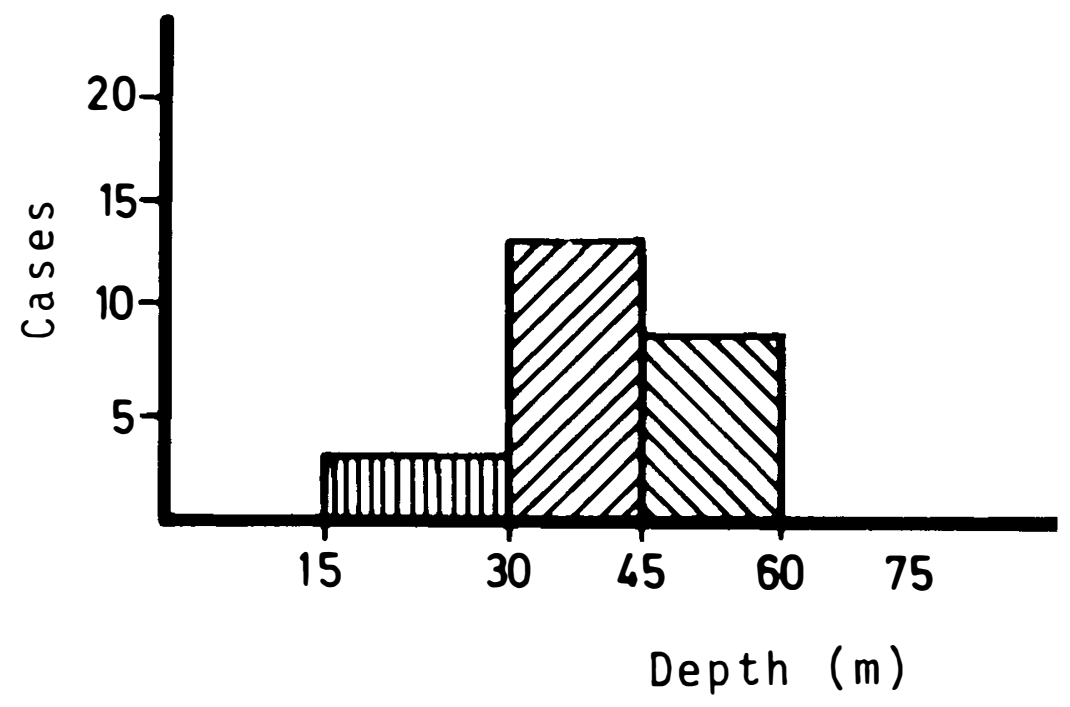

Figure 1. Maximum diving depth.

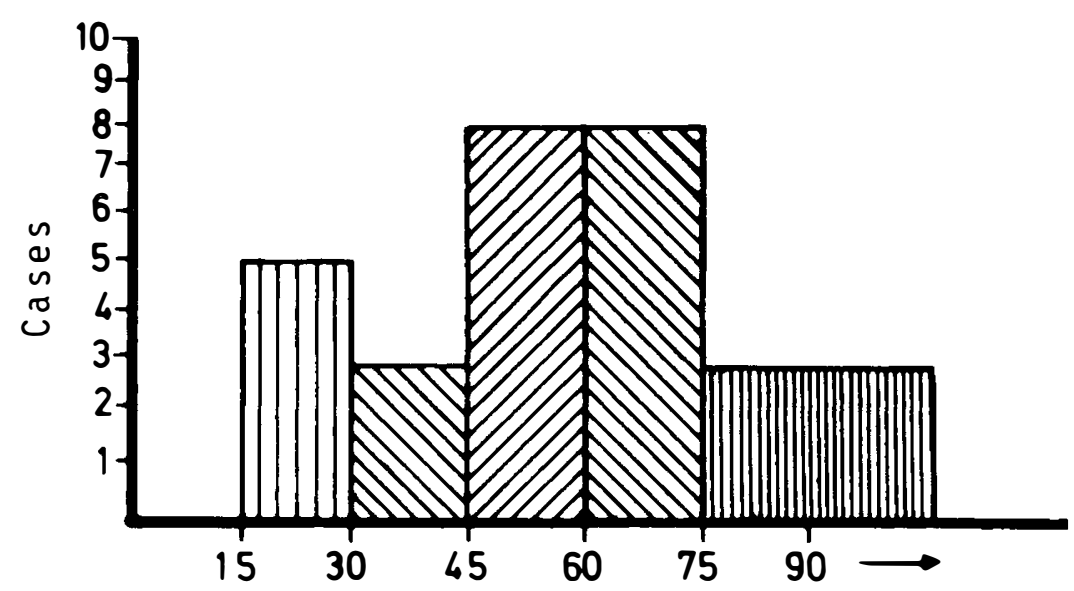

Time in min

Figure 2. Bottom time. 
hyperbaric treatment in the recompression chamber of Piraeus Naval Hospital over a period of 15 years. Furthermore, we chose 25 patients who showed abnormalities on passing urine and demanded catheterisation.

All were men and 17 were professionals; 18 were Greeks and the other seven were foreigners. There were eight patients above 40 while one was 55 -year-old. The maximum diving depth as well as the bottom time is shown in Figs 1 and 2 .

\section{Results}

The neurological signs appeared within the first hour of emergence from the water in $70 \%$ of the cases (Table 1). These signs are shown in Table 2 while the situation concerning micturition is shown in Table 3. All cases were diagnosed as type II Decompression sickness (DS) while 11 had clinical signs of type I DS as well. We have to emphasize the difficulties we face in classifying neurological symptoms since there are many possibilities for confusing these symptoms with pulmonary barotrauma or neurological effects of high pressurised nitrogen and prolonged inhalation of air with high oxygen content (Bennet and Towse, 1971; Kid and Elliot, 1975).

There were not studies of enzyme activities and coagulation factor. Only three patients had mild polycythemia after the treatment.

Table 1 Time of appearance of neurological signs after emerging from water

\begin{tabular}{ll}
\hline After 1 hour & $70 \%$ \\
After 2 hours & $20 \%$ \\
After 5 hours & $10 \%$ \\
\hline
\end{tabular}

Table 2 Clinical signs (urinary not included)

\begin{tabular}{lr}
\hline Signs & Cases \\
\hline Localised pain & 7 \\
Paraplegic & 9 \\
Tetraplegic & 2 \\
Hemiplegia & 1 \\
Monoparesis & 2 \\
Visual disturbances & 1 \\
Hearing disturbances & 2 \\
Fatigue & 7 \\
Nausea-vomiting & 5 \\
Paraesthesia & 4 \\
Abdominal pain & 5 \\
Respiratory disturbances & 7 \\
Erythema & 3 \\
\hline
\end{tabular}

Table 3 Urinary symptoms

\begin{tabular}{lr}
\hline Symptoms & Cases \\
\hline Retention of urine & 14 \\
Painful retention & 2 \\
Overflow & 3 \\
Dysuria & 6 \\
\hline
\end{tabular}


Table 4 Micturition af ter recompression

\begin{tabular}{lccc}
\hline & Good & Satisf actory & Retention \\
\hline On exit & 3 & 12 & 10 \\
1 week later & 5 & 14 & 6 \\
2 weeks later & 10 & 11 & 4 \\
4 weeks later & 17 & 5 & 3 \\
16 weeks later & 17 & 5 & 3 \\
\hline
\end{tabular}

The 14 patients with obvious disturbances of micturition were all catheterised with a Foley catheter just before the admission into the chamber. Intermittent catheterisation was used for 11 patients during recompression. The patients' urination after the treatment is shown in Table 4.

Five months after discharge from the hospital eight patients still had some difficulty with micturition, three who were paraplegic had endoscopic surgery. Two cases underwent a sphincterotomy and one patient was submitted to transurethral prostatectomy because of a residual urine of over $250 \mathrm{ml}$; the results were good in all three patients.

All patients with urinary problems (except one) had descended to a depth of $35-40 \mathrm{~m}$. There was a correlation between the time of starting of symptoms and the degree of urinary disturbances. The earlier the disease appeared the more serious were the urinary problems.

Difficulty in passing urine was not recorded with type I decompression sickness.

\section{Case report}

A 40-year-old sponge fisher was working $45 \mathrm{~m}$ under water with a bottom time of $60 \mathrm{~min}$. Then he began to ascend and stopped at $10 \mathrm{~m}$ for $10 \mathrm{~min}$. Immediately after emerging from the water he felt severe chest pain and became unconscious. Two hours later he recovered but was paraplegic. He had dived at $20 \mathrm{~m}$ for 3 min, $18 \mathrm{~m}-5 \mathrm{~min}, 15 \mathrm{~m}-20 \mathrm{~min}, 12 \mathrm{~m}-30 \mathrm{~min}, 9 \mathrm{~m}-15 \mathrm{~min}, 6 \mathrm{~m}-10 \mathrm{~min}$ and when he ascended he could even walk with only paraesthesia of the legs. 30 min later he dived again at $15 \mathrm{~m}$ following the above rhythm of ascending but when he reached the surface he was unable to move his legs. Because of bad weather conditions he was only transported to the recompression chamber 20 hours later. Before entering the chamber he was catheterised with a Foleycatheter because of complete urinary retention. Two days later the chest pain disappeared and motor power recovered in his legs; micturition was successful 17 days later. The patient underwent physiotherapy with satisfactory results.

\section{Discussion}

Decompression sickness is not rare among sponge-divers in Greece. This was very provocative for Greek doctors. Katsaras, in 1886 reported a study of 60 cases with complete analysis of the clinical picture and the pathological lesions in the nervous system and proposed recompression.

In decompression sickness the uncontrolled ascent from diving creates a mass of gas bubbles in the tissues or blood vessels. Since the site or location of the 
bubbles can be anywhere in the higher centres, the spinal cord or the cardiorespiratory system, the symptomatology is protean and always unpredictable. Cerebral signs are severe headaches, nausea, vomiting, visual disturbances, nystagmus, loss of consciousness, disorientation, and confusion. Pulmonary signs consist of dyspnoea with extreme anxiety. Involvement of the spinal cord results in weakness of the extremeties, paraesthesiae, monoparesis, paraparesis, paraplegia and tetraplegia.

There are anatomical as well as physiological reasons for the spinal cord drainage in severe decompression sickness. Regions of the epidural vertebral venous system (Batson's) communicate with the cranial dural sinuses, with the posterior bronchial and parietal-pleural veins, with the ascending lumbar veins in the abdomen and with the azygos and the vertebral veins in the thorax and neck (Batson, 1940).

The flow rate in this valveless system is very low and the direction of the flow changes frequently. Bubbles collect, grow or coalesce and obstruct this system more frequently than the cranial or cerebral veins (Melamed and Ohry, 1980).

In our study we found out that seven divers had some respiratory problem; this is similar to that reported in other studies (Behnke and Shaw, 1937; Elliot et al., 1974).

We also found out that up to $53 \%(25 / 48)$ of all cases treated, showed a mild or severe urological complication. The lower thoracic segment was the part of the spinal cord which was mainly affected; this is comparable with other studies (Katsaras, 1886; Melamed and Ohry, 1980).

There are some special reasons which can explain why Greek sponge divers do not keep strictly to the rules when emerging from the water (Jordanides, 1978).

\section{(a) The particular mentality of the divers}

These people are members of a close community; so it is very difficult for them to accept any new suggestions. They work in their traditional way and any new scientific views are not easily acceptable. Their longtime experience has persuaded them that 'not keeping the rules' is not always dangerous.

\section{(b) The employer-sponge diver economic relation}

Different rates of decompression sickness have been observed between the sponge divers of Kalimnos and Limnos (Aegean, islands). At Kalimnos, where there are more victims than at Limnos, the sponge divers participate in the profit proportionally to the personal fishery; so they dive without taking any special precautions. On the contrary Limnian sponge divers are day-labourers and their participation in the profit is independent from the personal fishery; thus they are not too zealous concerning their work.

Although there are interesting analogies between modern therapy and ancient empirical methods, (Viotti and Ferrigno, 1983) we must emphasize that the divers should be better informed and that initial treatment is mandatory.

We also believe that patients with urinary disturbances must undergo catheterisation before entering the chamber. 


\section{Acknowledgements} We gratefully thank Dr T. Jordanidis, consultant neurologist to Naval Hospital
of Piraeus for allowing us to include a number of patients who were under his care.

\section{Résumé}

On a revu les fiches de 25 malades qui souffraient de la maladie de décompression du type 11 accompagnée de problèmes urinaires. Dix-sept malades étaient professionnels et 8 en étaient audessus de l'âge de 40 ans. La maladie s'est montrée au cours de la première heure d'émergence de l'eau chez $70^{\circ}$ o des cas et au cours des 4 premières heures chez les $30^{\circ}$ o qui restaient. Neuf malades ont été diagnosés comme paraplégiques et deux comme tétralégiques. Tous les malades avaient des perturbations urinaires et 14 en subissaient le drainage à cathéter de Foley pendant la décompression tandis que 11 en subissaient la cathétérisation intermittente. Quinze malades avaient la fonction urinaire améliorée après la récompression, 8 en avaient quelque difficulté, 2 ont subi une sphinctérotomie et un malade a subi une prostatectomie transurétrale. Le pourcentage réduit de rétablissement complet était dû à l'arrivée retardée en chambre de décompression.

\section{Kurzverfassung}

Man hat die Berichte über 25 Patienten mit Druckabnahmekrankheit der Type 11 zusammen mit Harnproblemen durchgesehen. Siebzehn Patienten waren Beruf sleute, und 8 waren mehr als 40 Jahre alt. Die Krankheit ist während der ersten Stunde nach Auftauchung vom Wasser bei $70^{\circ}{ }_{0}$ der Fälle und im Laufe der ersten 4 Stunden bei den übrigen $30^{\circ}$ o erschienen. Neun Patienten sind als paraplegisch und zewi als tetraplegisch bestimmt worden. Sämtliche Patienten hatten Harnbeschwerden, und 14 wurden mit Foley-Katheter-Dränage unter der Druckabnahme behandelt, während 11 mit intermittierendem Katheterismus behandelt wurden. Fünf zehn Patienten hatten verbesserte Harnfunktion nach der Wiederdruckbeanspruchung, 8 hatten etwas Schwierigkeit, 2 unterzogen sich einer Sphinkterotomie, und einer unterzog sich einer transuretralen Prostatektomie. Der niedrige Prozentsatz der völligen Wiederherstellung war wegen der verzögerten Ankomst nach der Druckabnahmekammer.

\section{References}

BATSON OV 1940 The function of the vertebral veins and their role in the spread of metastasis. American Surgeon 112:138-149.

BEHNKE R, SHAw A 1937 The use of oxygen in the treatment of compressed air illness. Naval Medical Bulletin 35:61-63.

BENNET PB, TowsE EJ 1971 The high pressure nervous syndrome during a simulated oxygenhelium dive to $1.500 \mathrm{ft}$. Electroencephalography and Clinical Neurophysiology 31:383-393.

Elliot DH, Hallenbeck JM and Bove AA 1974 Acute decompression sickness. Lancet 2:1193-1199.

JoRDANIDES T 1978 The decompression sickness. Thesis, University of Athens.

KID D, Elliot D 1975 Physiology and Medicin of Diving, p. 478, Bennett and Elliot, London.

KATSARAS M 1886 Recherches cliniques et experimental sur les accidents survenant par l'emploi de scaphandres. Archives de Neurologie, Vol. XVI, 47.

Melamed Y, Ohry A 1980 The treatment and the neurological aspects of diving accidents in Israel. Paraplegia, 18:127-132.

Viotti G, FERrigno M 1983 Trattamenti empirici della MDD presso i pescatori di spugne greci. Minerva Medica, 74:2001-2004. 